\title{
Staphylococcus aureus osteomyelitis causing Brodie's abscess of the tibia in an adult man
}

\author{
Benjamin C Chen (ㄷ), ${ }^{1}$ Takaaki Kobayashi 이, ${ }^{1}$ Howard O'Rourke, ${ }^{2}$ Poorani Sekar ${ }^{1}$
}

${ }^{1}$ Internal Medicine, The University of lowa Hospitals and Clinics, lowa City, lowa, USA ${ }^{2}$ Radiology, The University of lowa Hospitals and Clinics, lowa City, lowa, USA

\section{Correspondence to} Dr Benjamin C Chen; benjamin-chen@uiowa.edu

Accepted 16 December 2020

\section{DESCRIPTION}

A 50-year-old man with a childhood history of right tibial fracture managed non-operatively with traction pin placement was referred to the orthopaedics clinic. He had several months of worsening right lower leg pain, warmth and swelling in the absence of systemic fever or chills. On presentation, his temperature was $36.5^{\circ} \mathrm{C}\left(97.7^{\circ} \mathrm{F}\right)$. Laboratory tests revealed a white blood cell count of $12.1 \times 10^{9} / \mathrm{L}$ (normal 3.7-10 $\times 10^{9} / \mathrm{L}$ ), an erythrocyte sedimentation rate of $45 \mathrm{~mm} /$ hour (normal $0-20 \mathrm{~mm} /$ hour) and a $\mathrm{C}$ reactive protein of $4.8 \mathrm{mg} / \mathrm{dL}$ (normal $<0.5 \mathrm{mg} / \mathrm{dL}$ ). A venous duplex ultrasound was performed which was negative for thrombus. MRI revealed a $0.7 \times 1.2 \mathrm{~cm}$ proximal tibial fluid collection with peripheral enhancement and a penumbra sign (figure 1), consistent with Brodie's abscess with subacute osteomyelitis. The patient underwent CT scan-guided aspiration of the fluid collection. Pathology revealed osteomyelitis with no concern for malignancy and cultures showed methicillinsusceptible Staphylococcus aureus. The patient underwent debridement of the tibia wherein purulence was noted within the medullary cavity but not outside the bone. The fluid collection was irrigated thoroughly, and antibiotic-impregnated cement beads were placed into the bone defect (figure 2). The patient was discharged home to complete 6 weeks of intravenous cefazolin. At 3-week follow-up in the infectious diseases clinic, intravenous antibiotics were discontinued due to rapid clinical improvement and the patient was transitioned to oral doxycycline for the remaining
3 weeks of therapy. The patient continued to do well clinically after completion of antibiotics.

Brodie's abscess is a subacute-to-chronic manifestation of osteomyelitis presenting as a pus collection within the bone, often with an indolent onset. ${ }^{1}$ Sir Benjamin C. Brodie first described this phenomenon in 1832 in a 24-year-old man with chronic pain and swelling of the ankle, later found to have a walnut-sized pus collection within the tibia after amputation. ${ }^{2}$ In a systematic review examining 407 patients, Brodie's abscess most frequently involved the tibia (49\% of cases) and femur (31\% of cases). ${ }^{1}$ Diagnosis is challenging as patients commonly present with pain and swelling in the absence of fever. Inflammatory markers and blood cultures are often unrevealing, necessitating a high degree of suspicion to diagnose this variant of osteomyelitis. Imaging is essential in the work up of Brodie's abscess, with a characteristic 'target sign' on MRI consisting of central necrosis, adjacent granulation tissue, surrounding fibrosis or sclerosis and an outermost layer of oedema. ${ }^{3}$ Biopsy can be helpful to exclude alternate diagnoses such as bone neoplasm. Case series at a quaternary referral centre in the southeast $\mathrm{USA}^{4}$ and two tertiary referral centres in southwestern Nigeria ${ }^{5}$ demonstrate a male predominance of this condition, with the highest prevalence in patients below the age of 30. Staphylococcus aureus is most often implicated in Brodie's abscess formation, either through haematogenous spread or direct inoculation into the bone. ${ }^{45}$ Outcomes are generally favourable in the literature with a combination of surgical
D) Check for updates

(C) BMJ Publishing Group Limited 2021. No commercial re-use. See rights and permissions. Published by BMJ.

\footnotetext{
To cite: Chen $B C$, Kobayashi T, O'Rourke H, et al. BMJ Case Rep 2021;14:e240836. doi:10.1136/bcr-2020240836
}

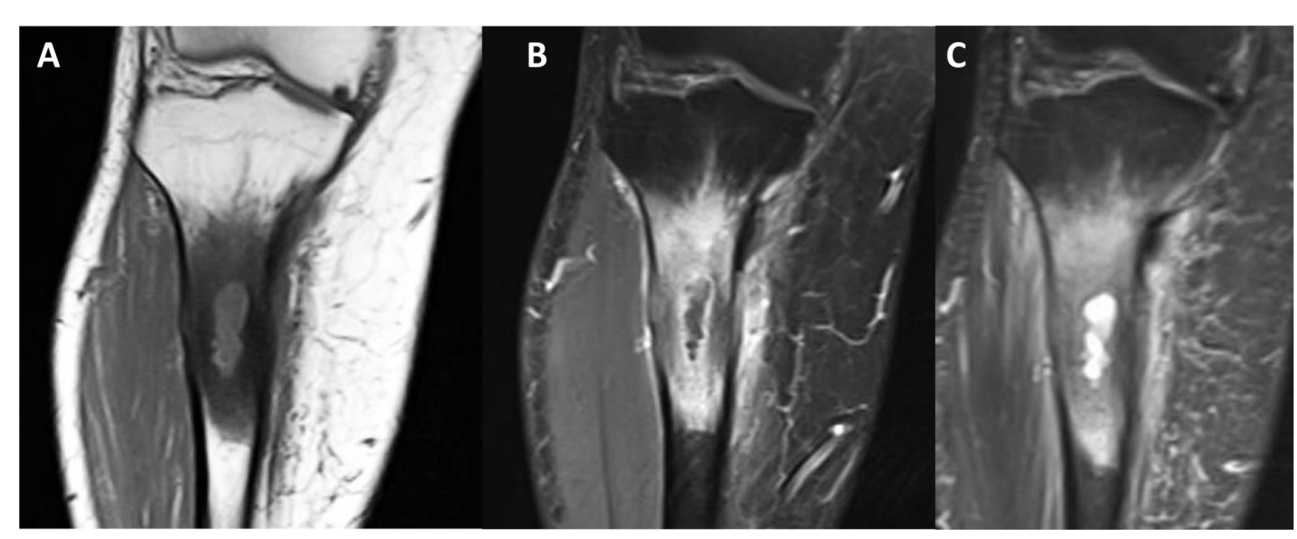

Figure 1 (A) Coronal T1 MRI shows fading sclerosis and a penumbra sign around the proximal tibia Brodie's abscess. (B) Coronal T1 fat-saturated postcontrast image shows peripheral enhancement and surrounding bone and soft tissue oedema around the intraosseous abscess. (C) Coronal T2 fat-saturated image shows a fluid collection in the proximal tibia with surrounding bone oedema consistent with Brodie's abscess. 


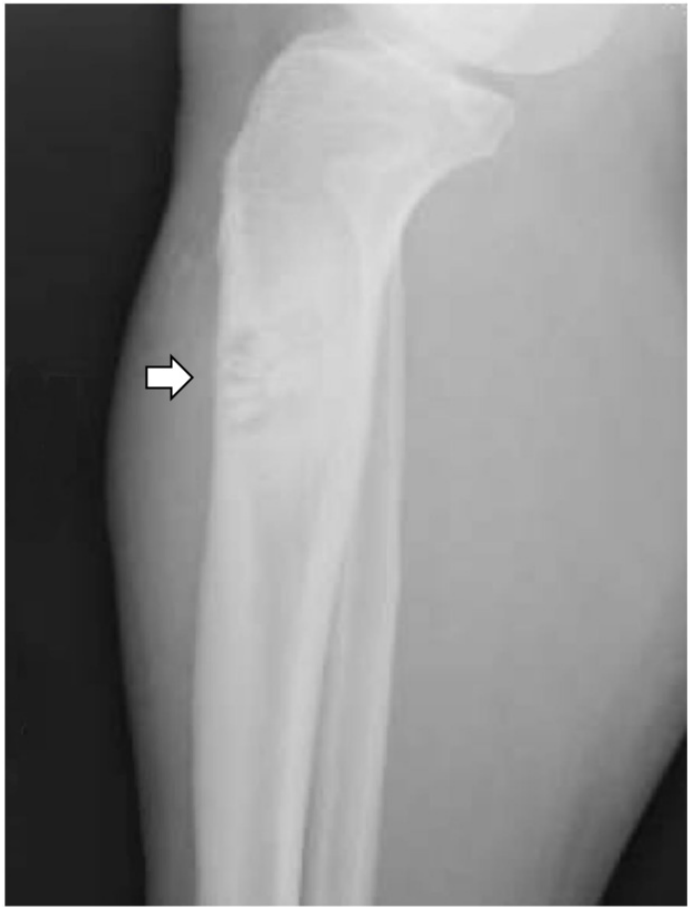

Figure 2 Postoperative plain film radiograph of the right leg demonstrating antibiotic-impregnated cement beads within the bone defect.

debridement followed by prolonged parenteral or oral antibiotics, although the optimal duration of antibiotics is not well characterised. Our patient demonstrated clinical improvement after surgical source control and 6 weeks of antibiotics with complete resolution of symptoms.

Contributors $B C C$ wrote the first draft of the manuscript. TK, HO'R and PS critically reviewed and revised the manuscript. All authors read and approved the final paper.

\section{Learning points}

- Brodie's abscess is an atypical manifestation of subacute osteomyelitis that presents with subtle clinical findings and often normal laboratory values. The tibia and femur are the most frequently involved sites.

- Brodie's abscess demonstrates a characteristic target sign on MRI consisting of concentric layers of necrosis, granulation, sclerosis and oedema.

- Management of Brodie's abscess consists of surgical debridement followed by a prolonged course of parenteral or oral antibiotics, with favourable outcomes reported in the literature.

Funding The authors have not declared a specific grant for this research from any funding agency in the public, commercial or not-for-profit sectors.

Competing interests None declared.

Patient consent for publication Obtained.

Provenance and peer review Not commissioned; externally peer reviewed.

\section{ORCID iDs}

Benjamin C Chen http://orcid.org/0000-0003-4232-2457

Takaaki Kobayashi http://orcid.org/0000-0003-4643-4798

\section{REFERENCES}

1 van der Naald N, Smeeing DP, Houwert RM. Brodie's Abscess: A Systematic Review of Reported Cases. J Bone Joint Infect 2019;4:33-9.

2 Brodie BC. An account of some cases of chronic abscess of the tibia. Med Chir Trans 1832;17:239-49.

3 Gould CF, Ly JQ, Lattin GE, et al. Bone tumor mimics: avoiding misdiagnosis. Curr Prob/ Diagn Radiol 2007;36:124-41.

4 Foster CE, Taylor M, Schallert EK, et al. Brodie abscess in children. Pediatr Infect Dis J 2019;38:e32-4.

5 Olasinde AA, Oluwadiya KS, Adegbehingbe 00. Treatment of Brodie's abscess: excellent results from curettage, bone grafting and antibiotics. Singapore Med J $2011 ; 52: 436-9$

Copyright 2021 BMJ Publishing Group. All rights reserved. For permission to reuse any of this content visit

https://www.bmj.com/company/products-services/rights-and-licensing/permissions/

BMJ Case Report Fellows may re-use this article for personal use and teaching without any further permission.

Become a Fellow of BMJ Case Reports today and you can:

- Submit as many cases as you like

- Enjoy fast sympathetic peer review and rapid publication of accepted articles

- Access all the published articles

- Re-use any of the published material for personal use and teaching without further permission

Customer Service

If you have any further queries about your subscription, please contact our customer services team on +44 (0) 2071111105 or via email at support@bmj.com.

Visit casereports.bmj.com for more articles like this and to become a Fellow 